DOI: $10.19195 / 2353-8546.4 .6$

\author{
LIDIA MIĘSOWSKA* \\ Uniwersytet Śląski (Sosnowiec, Polska)
}

\title{
Między postkomunizmem a postmodernizmem. Najnowszy dramat rosyjski w poszukiwaniu tożsamości kulturowej
}

Between post-communism and postmodernism. The new Russian drama in search for its cultural identity. Russian drama after 1991, suspended between memory and oblivion, attempts to process an overwhelming trauma of its own tragic history. Evgeny Grishkovets, Vladimir Sorokin, Ludmila Petrushevskaya, Alexey Shipenko, Oleg Bogayev, Vasily Sigarev, the Presnyakov brothers, Ivan Vyrypaev and others show experiences preceding and following Perestroika and demonstrate the scale of traumatic consequences of old structures disintegration as well as dangers connected with entering the area of freedom. This way Russian drama underwent all the development stages ranging from admiration for freedom to its negation, all the time without losing an interest in the internal man. Therefore criticism of the communist ideology as a kind of utopia and visions showing the risk of the rebirth of totalitarianism in Russia coexist along with the stream of consciousness depicting what is happening in the soul of a contemporary Russian. The process of self-identification of the human being that is decentralised, standardised and attached to stereotypes of mass awareness takes place within the framework of postmodernist mixture of stylistics and aesthetics, deconstruction of the reality and the language, play with culture codes, which is most fully expressed through the ongoing process of searching for cultural identity of the discussed works.

Keywords: Perestroika, postmodernism, post-communism, identity, Sorokin

* Adres do korespondencji: Instytut Filologii Wschodniosłowiańskiej UŚ, ul. Grota-Roweckiego 5, 41-205 Sosnowiec. E-mail: lidia.miesowska@us.edu.pl. 
Между посткоммунизмом и постмодернизмом. Современная русская драматургия в поисках культурной идентичности. Русская драматургия после 1991 года, зависшая между памятью и забвением, пытается проработать сковывающую травму своей трагической истории. Евгений Гришковец, Владимир Сорокин, Людмила Петрушевская, Алексей Шипенко, Олег Богаев, Василий Сигарев, братья Пресняковы, Иван Вырыпаев и др. показывают опыт «до» и «после» революции (перестройки), демонстрируют масштаб травматических последствий распада предыдущих структур, а также опасности, сопряженные с вхождением в сферу свободы. Таким образом, драматургия в России прошла все стадии развития - от восторга до отрицания свободы, не теряя одновременно заинтересованности внутренним человеком. Отсюда критика утопического характера коммунистической идеологии или образы, указывающие на опасность возрождения тоталитаризма в России, которые сосуществуют с потоком сознания, воссоздающим то, что происходит в душе современного русского человека. Процесс самоидентификации децентрализованного, стандартного и привязанного к стереотипам массового сознания человека происходит в рамках постмодернистского смешения стилистик и эстетик, деконструкции действительности и языка, игры с культурными кодами, что наиболее полно показывает незаконченный процесс поиска культурной идентичности обсуждаемого творчества.

Ключевые слова: перестройка, постмодернизм, посткоммунизм, идентичность, Сорокин

Istotę najnowszego teatru i dramatu rosyjskiego trafnie wyraża konstatacja Władimira Sorokina, który z perspektywy ćwierćwiecza bardzo surowo ocenia niedawną przeszłość czasów Borysa Jelcyna oraz rosyjską współczesność. W wywiadzie opublikowanym w tygodniku „Die Zeit” mówi, że podstawowy błąd Jelcyna polegał na tym, że zupełnie inaczej niż Niemcy, którzy „pogrzebali trupa nazizmu”, nie „,zakopał trupa sowieckiego”. „Rosjanie powiedzieli sobie: odłożymy tego trupa na bok i przysypiemy trocinami, to sam zgnije" - tłumaczy pisarz, dodając, że skutki braku desowietyzacji cały kraj odczuwa do dzisiaj ${ }^{1}$. Na sytuacji współczesnego dramatu w Rosji bez wątpienia zaważył trudny i burzliwy okres reform ogłoszonej w połowie lat osiemdziesiątych XX wieku pieriestrojki oraz czas bezpośrednio po upadku Związku Radzieckiego (1991). Dramat lat osiemdziesiątych-dziewięćdziesiątych niezwykle żywo reagował na podlegającą transformacjom sowiecką rzeczywistość i prezentował już wtedy niesłychaną różnorodność tendencji artystycznych. Niebanalny wpływ na taki obraz dramaturgii miał fakt, że na arenie literackiej działali wówczas pisarze pokolenia starszego, np. Aleksiej Arbuzow, Wiktor Rozow, Aleksander Sztejn, Michaił Szatrow, Aleksandr Gelman, oraz

grupa młodych, energicznych autorów, nazywana potem przez krytykę „nową falą”, która coraz śmielej zaczęła poddawać analizie te sfery współczesności, które w warunkach radzieckich były, jeśli już nie pomijane, to określane jako obce społeczeństwu realnego socjalizmu².

${ }^{1}$ W. Sorokin, Rosja przypomina nieuleczalnie chorego w stanie agonii. Rozmowa W. Sorokina z „Die Zeit”, http://wyborcza.pl/1,91446,16895314,Niemcy_Sorokin_Rosja_przypomina_nieuleczalnie_chorego.html [dostęp: 27.02.2015].

2 W. Piłat, Współczesna dramaturgia rosyjska. Lata osiemdziesiąte, Olsztyn 1995, s. 9. 
„Orzeźwiający przypływ nowej fali”3, sygnowanej nazwiskami pisarzy takich, jak m.in. Ludmiła Pietruszewska, Aleksiej Kazancew, Aleksiej Dudariew, Aleksander Galin, Władimir Arro, Siemion Złotnikow, Wiktor Sławkin, Michaił Worfołomiejew, nie tylko przyniósł nowoczesnej dramaturgii radzieckiej nową tematykę i problematykę, ale też zmusił ją do poszukiwań nowych form wyrazu artystycznego.

Wprowadzenie do dramaturgii okresu pieriestrojki „Zwykłego” człowieka, pozornie szarego, poddanego wpływom załamującej się rzeczywistości radzieckiej zaowocowało szczerymi obrazami rozpadu rodziny, obrazami zmagań bohaterów z dylematami moralnymi, opisami postaw człowieka wobec trudnych wyborów. Pisarze próbowali także pogłębiać rys psychologiczny swoich bohaterów, pokazując destrukcyjny wpływ kultu jednostki i zbrodni stalinowskich na świadomość zwykłego człowieka. Prócz tego następowała zmiana pozycji literatury i roli autora, który zaczynał ujawniać swój krytyczny stosunek do kreowanego świata przedstawionego. Jak zauważa Maria Czerniak:

Wielu współczesnych krytyków zgadza się w opinii, że pod koniec XX wieku skończyła się epoka literatury [...]. Jeżeli w ciągu prawie dwóch wieków aktualne były słowa Aleksandra Hercena o tym, że "dla narodów pozbawionych wolności społecznej literatura staje się jedyną trybuną, z której naród może powiedzieć o swoim bólu", to dziś wychowawcza, edukacyjna misja literatury rosyjskiej nie jest już tak wyraźna ${ }^{4}$.

Efektem tych przeobrażeń był też zupełnie nowy język, jakim posługiwały się postaci dramatu, maksymalnie nasycony emocjami dzięki wykorzystaniu formy pozornego dialogu i wzbogaceniu stylistyki o żargon, frazeologizmy, aforyzmy, język niestroniący od wulgaryzmów, ironizujący z radzieckiej „nowomowy”. „Kryzys wysokiego stylu estetycznego i tradycji literackiej. Kryzys imperialnej świadomości. Kryzys humanizmu. Ale każdy z nowych pisarzy zyskiwał swój język, odnajdywał swoją formę. Rodziła się nowa rzeczywistość - a z nią nowe znaczenia” - powie o tych zmianach Oleg Pawłow ${ }^{5}$.

Rozpoczęcie przez Michaiła Gorbaczowa w 1985 roku reform wszystkich dziedzin życia społeczeństwa, wówczas jeszcze sowieckiego, poskutkowało więc powolnym wycofywaniem się z życia literackiego dramatu publicystycznego, jak określano dramat produkcyjny, dramatu schematycznego, przedstawiającego uproszczony, „lakierowany" obraz rzeczywistości i działających w niej kartonowych, biało-czarnych zideologizowanych postaci.

W tym czasie literatura wyzwoliła się spod wpływów dyrektyw partyjnych, określających reguły, ,jak i co pisać”, sięgnęła po tematy i rozwiązania formalne

3 Tak Walenty Piłat zatytułował rozdział swej książki, poświęcony zjawisku „nowej fali” w dramaturgii lat osiemdziesiątych. Zob. ibidem, s. 71-108.

${ }^{4}$ Opinię Marii Czerniak (М. Черняк, Современная русская литература, Москва 2008, s. 7-8) cytuję za: E. Borkowska, „Russkij malczik” - bohater współczesnej literatury rosyjskiej, „Adeptus. Pismo Humanistów" 2013, nr 2, s. 44.

5 О. Павлов, Остановленное время, „Континент” 2002, nr 113, s. 382-385. Cyt. za: E. Borkowska, op. cit., s. 45. 
dotychczas zakazane przez czynniki oficjalne. Jednak wydaje się, że rację ma Jean Baudrillard, twierdząc, iż: „System komunistyczny i mur berliński nie zawaliły się na zewnątrz, na znak otwarcia i wolności, lecz do wewnątrz, na znak rozpadu, gwałtownej dekonstrukcji - ale bez wyzwolicielskich konsekwencji. One zniszczyły się same, robiąc miejsce pustce - jak zapadające się domy"6.

Entuzjazm, jaki towarzyszył odzyskaniu wolności, okazał się w rzeczywistości tyleż budujący, co destruujący, szczególnie z powodu rodzącej się w pisarzach niepohamowanej chęci negowania zastanego porządku świata. Do literatury wkradł się chaos i swego rodzaju „artystyczne bezprawie”. Siergiej Czuprynin w 1997 roku tak charakteryzował ówczesną sytuację:

realizm, naturalizm, konceptualizm, postmodernizm i inne „izmy” rozsypały się i górę wzięły pisarskie indywidualności. Za polityczną bezpartyjnością podążyła bezpartyjność estetyczna. W każdym razie po byłej polaryzacji, rozpadzie na wrogie sobie pokolenia i klany nie ma nawet śladu. Prywatne znalazło się ponad wspólnym... Książki stały się ważniejsze i ciekawsze od tendencji .

Warto dodać, że coraz bardziej zacierała się granica między sztuką wysoką i kulturą masową, a publikowane $\mathrm{w}$ tym czasie teksty powstawały często pod szyldem kiczu i chałtury. Natomiast świadomość zbliżającego się końca stulecia zmuszała twórców do podejmowania prób przewartościowania świata i przeprowadzenia obrachunków z niedawną przeszłością, czego efekt opisywał Baudrillard:

Ten bolesny rewizjonizm niewątpliwie przybiera postać nekrologiczną. Dzięki temu od lat osiemdziesiątych znajdujemy się w przestrzeni „nekro”. Nekrosocjalizm w uścisku z własnym trupem i trupem historii. Nekromitterandyzm, ghostpresident, który wampiryzuje odwapnione społeczeństwo. Agonia wielkich narracji i wszystkich ideałów nowoczesności. Dokonany w kilka lat holocaust całego pokolenia intelektualnych kacyków (Sartre, Barthes, Lacan, Foucault, Althusser, Deleuze, Debord). Niewyobrażalna nekrofagia wspomnień (rok 68, rewolucja francuska, Rimbaud, Nietzsche, Van Gogh, czy co tam jeszcze, nie licząc przypadku Heideggera i wszystkich nekroaktywnych konwulsji związanych z eksterminacją i wojną). Upadek Muru i koniec komunizmu, praca żałoby jeszcze nie skończona, ale tym razem to nie widmo komunizmu nawiedza historię, lecz minione widmo komunizmu nawiedza koniec historii — być może nastraszy ją bardziej jako martwe niż jako żywe? ${ }^{8}$

Przestrzeń wolności, w jakiej znaleźli się twórcy dramatu po upadku imperium radzieckiego, była jednocześnie swego rodzaju przestrzenią posttraumatyczną w rozumieniu Dominicka LaCapry, przestrzenią, w której „przeszłość wciąż żyje »W doświadczeniu«, skłonna do nawiedzania jednostek czy zbiorowości, wbrew

${ }^{6}$ Cytuję tutaj refleksje, jakie padły z ust Baudrillarda podczas rozmowy, którą przeprowadził z nim Philippe Petit, i które opublikowane zostały w: J. Baudrillard, Przed końcem. Rozmawia Philippe Petit, tłum. R. Lis, Warszawa 2001, s. 18.

7 Zdanie Sergieja Czuprynina (С. Чупринин, Есть ли у „знамени” будущее? Двенадиать мнений о перспективах русских литературных журналов, „Знамя” 1997, nr 1, s. 207) суtuję za: E. Borkowska, op. cit., s. 44.

${ }^{8}$ Ibidem, s. 82. 
pozornemu oddaleniu, skończeniu i zamknięciu”" . Wspomniani przedstawiciele „nowej fali” nie potrafili do końca skorzystać z danej im wolności, ponieważ nadal ciążyło nad nią właśnie owo „minione widmo komunizmu”. Wyczuwało się je na każdym poziomie struktury tekstu, w którym podejmowana problematyka nie pozwalała zapomnieć o przeszłości: szarzy bohaterowie egzystowali w ciasnych i śmierdzących komunałkach czy chruszczowkach — symbolach radzieckiej rzeczywistości, skazani na umasowienie i tandetę zapominali o najprostszych ludzkich odruchach, obchodzili się z sobą niezwykle brutalnie, deptali własne uczucia, niszczyli łączące ich więzi i na zgliszczach normalności próbowali budować swą teraźniejszość czy przyszłość.

Zdeformowani przez czasy komunizmu protagoniści „nowofalowych” sztuk marzyli o wyzwoleniu się ze schematów dawnego życia, jednocześnie nie umieli zaakceptować nowych realiów. Ten problem dotykał także młodego pokolenia, które często występowało w roli bohatera ówczesnych sztuk. To pokolenie, buntownicze, odczuwające potrzebę negowania zastanego porządku nie widziało przed sobą żadnej przyszłości, na co wpływał z jednej strony brak poważnych autorytetów w ich życiu, z drugiej - męcząca świadomość mentalnego zakorzenienia w czasach głębokiego komunizmu. Uaktywnienie się pisarzy „nowej fali” nie mogło zatem doprowadzić do ostatecznego przerwania trwającej kilka dziesięcioleci „,iterackiej nekrozy”. Jeśli nawet przyniosło z sobą wolną od politycznego zaangażowania dramaturgię, to jednocześnie zrodziło potrzebę tworzenia dramatu zaangażowanego społecznie, dramatu, który przygotowywał się na kolejne, jeszcze bardziej zdecydowane transformacje.

Największe zasługi na tym polu należą z całą pewnością do Ludmiły Pietruszewskiej, uznanej za bezpośrednią spadkobierczynię nowatorskich dokonań Aleksandra Wampiłowa ${ }^{10}$, który mistrzowsko obnażał paradoksy radzieckiego życia w najprostszych jego przejawach, oddając $\mathrm{w}$ formie precyzyjnej mozaiki złożoną sytuację psychiczną tragikomicznych bohaterów, bezsilnych wobec swojej niemocy, bezradnych wobec dylematów duchowych i kompromisów moralnych, jakich doświadczali (np. Dom z widokiem na pole/Дом окнами в поле - 1963, Rozstanie w czerwcu/Прощание в июне - 1966, Polowanie na kaczki/Утиная охота - 1970, Zeszłego lata w Czulimsku/Прошльмм тетом в Чулимске - 1972). Pietruszewska, wyróżniająca się swą twórczością na tle pozostałych „nowofalowców”, zdołała pogłębić dramatyzm ukazy-

${ }^{9}$ D. LaCapra, Historia w okresie przejściowym. Doświadczenie, tożsamość, teoria krytyczna, tłum. K. Bojarska, Kraków 2009, s. 76.

10 Zob. prace W. Piłata i obszerną literaturę krytyczną w nich zawartą, np. Twórczość Aleksandra Wampiłowa. Z zagadnień poetyki, Olsztyn 1986; Kilka uwag o współczesnej dramaturgii radzieckiej, „Język Rosyjski” 1986, nr 1; Motyw „tragicznego błazna” w sztuce Antoniego Czechowa "Iwanow” i w dramacie Aleksandra Wampiłowa „Polowanie na kaczki”, „Slavia Orientalis” 1988, nr 1; Współczesna dramaturgia radziecka - teraźniejszość i perspektywy rozwojowe, „Slavia Orientalis” 1989, nr 1-2; Współczesna dramaturgia radziecka — od dokumentu do groteski, „Przegląd Humanistyczny” 1991, nr 1; Na progu XXI wieku. Szkice o współczesnej dramaturgii rosyjskiej, Olsztyn 2000. 
wanych sytuacji, spotęgować tragiczne zdarzenia, by jeszcze mocniej, niż jej mistrz Wampiłow, wyeksponować okrucieństwo i bezduszność relacji społecznych, w jakie uwikłani byli bohaterowie jej sztuk. Problemy kobiet, nad których losem najczęściej się pochyla, w bodaj najbardziej znanych sztukach, takich jak: Lekcje muzyki (Уроки музыки, 1973), Surowa noga, albo spotkanie przyjaciół (Сырая нога, или встреча друзей, 1973-1978), Moskiewski chór (Московский хор, 1984), Trzy dziewczyny w niebieskim (Три девушки в голубом, 1989), są znamienne dla opisywanego czasu transformacji. Pisarka bezkompromisowo przedstawia prawdę o najcięższych doświadczeniach swoich bohaterek, narażonych na nieustanne cierpienia z powodu rozpadu rodziny, aborcji, gwałtów, kompromisów, jakie są ich udziałem. Skupiając się na ciemnej stronie życia w czasach przemian, akcentuje czynniki destruujące małe społeczności, w których najlepiej uwidacznia się brak komunikacji i okaleczenie emocjonalne. Tyle samo uwagi poświęca Pietruszewska problemom uniwersalnym, nękającym człowieka od zarania dziejów: sprzeczności i złożoności ludzkich charakterów, które od zawsze łączą w sobie dobro i zło, nienawiść do świata i pokorę wobec niego. Wnikliwe rysunki psychologiczne postaci przyjmują u Pietruszewskiej formę współczesnego „szkicu fizjologicznego", w którym istotną funkcję w opisie postaci oraz przestrzeni, na jakie zostają one skazane, pełni język. To właśnie ukształtowanie stylistyczne twórczości najważniejszej reprezentantki „nurtu postwampiłowskiego”, jak często określa się „,nową falę”, wzbudzało swego czasu wiele negatywnych emocji wśród krytyki ${ }^{11}$. Dramaturgię Pietruszewskiej określała ona wówczas pogardliwie jako „dramaturgię magnetofonowych nagrań”, „dramaturgię fizjologiczną”, wskazując na determinujący stylistykę utworów „efekt magnetofonowy” zapisu obrazu rzeczywistości, czyli niezwykły realizm języka marginalnych społeczności, język zwykłego człowieka zmagającego się z przeciwnościami losu i Historią.

O Pietruszewskiej można także powiedzieć, że w swoich utworach świadomie rozprawia się z mitem imperium radzieckiego ${ }^{12}$. Obraz życia kobiet, o których pisze, zaprzecza bowiem pod każdym względem głoszonym oficjalnie hasłom, np. monumentalizmu, dumy z Rosji, powszechnego patriotyzmu, idei równouprawnienia itd. Jej bohaterki są dobrze wykształcone, inteligentne, błyskotliwe, ale przygniecione ogromem obowiązków rodzinnych, brakiem pieniędzy, zmęczeniem. Uwięzione w zaklętych kręgach, wyalienowane i skazane na małe mieszkanka czy wspólne pokoje marzą o prywatności i własnym pokoju. Nie tęsknią także za Moskwą, która unieszczęśliwia swoich mieszkańców, skazując ich na życie nędzniejsze niż żywot sióstr Czechowa. Samotność kobiet Pietruszewskiej, zupełne wycofanie się ich z ży-

${ }^{11}$ O recepcji sztuk Pietruszewskiej pisze wielokrotnie np. Piłat: „Nowa fala” we wspótczesnej dramaturgii radzieckiej, „Miesięcznik Literacki” 1984, nr 7, s. 59-66; Literatura i "pieriestrojka”. O najnowszej dramaturgii radzieckiej, „Język Rosyjski” 1990, nr 1, s. 6-11; Жанровые особенности современной одноактной пьесы, [w:] Автор. Жанр. Сюжет, red. В. Грешны, Калининград 1991, s. 118-123. Zob. też: М. Громова, Русская современная драматургия, Москва 1999, s. 100-122.

12 Zob. szerzej: E. Thompson, Dekonstruowanie Imperium - Ludmiła Pietruszewska, [w:] eadem, Trubadurzy imperium. Literatura rosyjska i kolonializm, tłum. A. Sierszulska, Kraków 2000, s. 311-346. 
cia publicznego, ich uprzedmiotowienie i ów podkreślany na każdym kroku duszący brak przestrzeni wyrażone w tekstach autorki Trzech dziewczyn $w$ niebieskim poprzez trywializację i kpinę podważają symbole imperialnej Rosji: duma z niej zostaje zastąpiona funkcjami fizjologicznymi i ekskrementami, a w miejsce świetlanej przyszłości pojawiają się ciągłe niedobory materialne, przestrzenne, emocjonalne.

„Nurt postwampiłowski” lat osiemdziesiątych XX wieku przygotował grunt dla charakteryzującej popieriestrojkową literaturę rosyjską postawy „totalnej negacji rzeczywistości i jej dotychczasowego obrazu w sztuce" ${ }^{13}$. W tej nowej przestrzeni kultury

odrzucenie i niemal całkowite zanegowanie starego paradygmatu kultury i literatury skutkowały uaktywnieniem się niespotykanej liczby różnorodnych, niekiedy bardzo od siebie odległych języków, którymi próbowano wszechstronnie opisać zasady nowego myślenia kulturowego. Doszło również do rozchwiania granic systemowych literatury, co dało asumpt do żywiołowego eksperymentatorstwa formalnego, stylistycznego, ideowego. W konsekwencji sfera literackości poszerzyła swoje terytorium o obszary zarezerwowane do tej pory dla paraliterackich czy wręcz nieliterackich działań ${ }^{14}$.

Stąd dalszy etap rozwoju współczesnej dramaturgii rosyjskiej charakteryzuje się obecnością (czasem nawet w ramach jednego tekstu) doświadczenia konceptualizmu, skrajnego naturalizmu czy poetyki teatru absurdu.

Kolejna odsłona najnowszego dramatu rosyjskiego końca lat dziewięćdziesiątych starego i pierwszej dekady nowego wieku określana jest przez krytykę mianem „nowej nowej fali”, „dramaturgii innej” czy „nowego dramatu”15 (ros. „новая новая волна”, „другая драматургия”; termin ros. „новая драма” nawiązuje do pojęcia „nowego dramatu początków XX wieku”, którym to charakteryzowano nowatorską twórczość między innymi Czechowa, dalej w rozważaniach stosuję skrót ND do oznaczenia tego ruchu artystycznego). Jego twórców można nazwać następną grupą „młodych gniewnych”, którzy pragną definitywnie zerwać z praktykami estetycznymi, dotychczas stosowanymi w scenopisarstwie. Wśród przedstawicieli ponownie można odnaleźć zarówno pisarzy młodszego pokolenia, którego „światopogląd” literacki dopiero się formuje, jak i dramaturgów artystycznie dojrzałych, mogących poszczycić się dobrze wypracowaną, indywidualną manierą pisarską, odnotowywanych przez krytyków i uznawanych przez świat teatru ${ }^{16}$. Łączy ich zatem nie data

13 Szerzej zob. A. Skotnicka-Maj, Literatura przyspieszonego rozwoju, „Dekada Literacka” 1999, nr 9/10, s. 4-5, 27.

${ }^{14}$ C. Juda, Literatura przełomu - konfrontacja zobowiązań ideowych i artystycznych. Prawdy i uzurpacje nowego porządku, [w:] Kultury słowiańskie między postkomunizmem a postmodernizmem 1989-2004, red. M. Dąbrowska-Partyka, Kraków 2009, s. 235.

${ }^{15}$ Krytyka stosuje wymiennie określenia opisujące tę nieformalną grupę pisarzy. Por. W. Piłat, Na progu XXI wieku, s. 111-169; М. Громова, ор. cit., s. 98, С.С. Васильева, Пути развития русской драматургии конца ХХ века, „Вестник ВолГУ”, серия 8, вып. 11, 2012, s. 96-101.

16 Pisarzy współtworzących dzisiaj pejzaż najnowszej dramaturgii rosyjskiej mamy niezliczone rzesze. Nie sposób tutaj wymienić wszystkich, którzy zajmują się pisaniem dramatów w Rosji. Przywołane wybiórczo nazwiska pokazują jednak, że ruch zwany Nowym Dramatem skupia wokół siebie pisarzy różnych pokoleń, bardzo często także udzielających się na gruncie innych sztuk (prozaicy, poeci, 
urodzenia, lecz wspólne doświadczanie rzeczywistości, podobne emocje towarzyszące opisywaniu świata oraz analogiczne postrzeganie zasad, na jakich współcześnie powstaje literatura, oraz roli, jaką odgrywa w społeczeństwie rosyjskim przełomu XX i XXI wieku. Twórcy, o których mowa, od samego początku chcieli przede wszystkim, by ich literatura nie była już antysowiecka, nastawiona na krytykę przeszłości, lecz - asowiecka ${ }^{17}$, wolna od wszelkich tematów i problemów związanych z imperium radzieckim, wolna od rozliczeń i moralizatorstwa. Twórczość ta programowo stroniła więc od problemów politycznych sensu stricto, zagadnień bezpośrednio z polityką związanych. Kontynuując tradycje „nowofalowców”, skupiała się raczej na skutkach drastycznych i czasem nieudolnych działań politycznych, społecznych i gospodarczych władzy, skutkach, które dotykały najmocniej zwykłych obywateli, skupionych w małych rodzinnych, przyjacielskich społecznościach. Niewątpliwie można się tutaj doszukać także kontynuacji pewnych tendencji rozrachunkowych odnotowywanych w prozie, poezji czy dramacie epoki zastoju (spuścizna A. Wampiłowa, L. Pietruszewskiej, W. Rasputina, J. Trifonowa, poetów-bardów) z tą różnicą, że na przełomie XX i XXI wieku literatura przestała się bać tematów ciężkich i nieprzyjemnych (społecznych raczej niż politycznych), zagadnień moralności/amoralności, kwestii związanych z patologiami społecznymi, chorobami psychicznymi, smrodem życia ${ }^{18}$. O tym wszystkim zaczęto pisać w sposób najprostszy, bez zbędnego psychologizowania i bez tradycyjnego moralizatorstwa ${ }^{19}$, uciekając się niejednokrotnie do ironii, kpiny, sarkazmu. Pragnąc dochować wierności także wielowiekowym

reżyserzy, aktorzy itd.): Olga Kuczkina (1936), Ludmiła Pietruszewska (1938), Aleksander Obrazcow (1944), Lew Korsunski (1946), Ludmiła Razumowska (1946), Igor Szpric (1946), Oleg Jerniow (1949), Nadieżda Ptuszkina (1949), Nina Sadur (1950), Andriej Zinczuk (1951), Władimir Sorokin (1955), Jelena Griemina (1956), Michaił Ugarow (1956), Maria Arbatowa (1957), Aleksiej Słapowski (1957), Nikołaj Kolada (1957), Aleksiej Szypienko (1961), Dmitrij Lipskierow (1964), Ksienia Dragunska (1966), Konstantin Kostienko (1966), Jewgienij Griszkowiec (1967), Oleg Priesniakow (1969), Oleg Bogajew (1970), Maksim Kuroczkin (1970), Olga Muchina (1970), Wiaczesław Durnienkow (1973), Władimir Priesniakow (1974), Iwan Wyrypajew (1974), Paweł Priażko (1975), Władimir Zujew (1976), Wasilij Sigariew (1977), Michaił Durnienkow (1978), Nina Bielenicka (1981), Irina Waśkowska (1981), Anna Baturina (1985), Dmitrij Bogosławski (1985), Jarosława Pulinowicz (1987). Warto podkreślić, że wśród aktywnie działających dramaturgów są dzisiaj wciąż przedstawiciele starszego pokolenia — mistrzowie i nauczyciele, którzy dbają o edukację i rozwój swoich podopiecznych. Organizują dla nich nowe festiwale teatralne, czytania sztuk, tworzą szkoły dramaturgów, dzięki którym odbiorcy mają okazję nie tylko zapoznać się najnowszymi sztukami, ale przede wszystkim usłyszeć o najzdolniejszych i najbardziej obiecujących osobowościach każdego sezonu teatralnego.

17 Zob. wypowiedź Marii Arbatowej z rozmowy Jelieny Kuzniecowej z młodymi dramaturgami: Посиделки перед дальней дорогой, „Театральная жизнь” 1992, nr 6, s. 8.

18 Wiktor Jerofiejew o nowej literaturze po 1985 roku pisze: „W literaturze, w której pachniały niegdyś polne kwiaty i siano, pojawiły się nowe zapachy. To smród. Śmierdzi wszystko: śmierć, seks, starość, złe jedzenie, życie codzienne”. Zob. Wikt. Jerofiejew, Rosyjskie kwiaty zła, tłum. A. Pomorski, „Literatura na Świecie” 1994, nr 7-8, s. 338.

${ }^{19}$ Przywoływany już tutaj Wiktor Jerofiejew, jeśli w ogóle dostrzega taką postawę we współczesnej literaturze, to mówi o niej: „,zakonspirowany wstydliwy moralizm pisarzy jurodstwujuszczich” (ibidem, s. 342). 
tradycjom literatury rosyjskiej, która zawsze skupiała się na kwestiach etycznych, $\mathrm{ND}$, stojąc u progu XXI wieku, starał się jednak uniknąć moralizatorstwa w tonie literatury łagrowej (Aleksander Sołżenicyn, Warłam Szałamow, Gieorgij Władimow), moralizatorstwa, które nie przemawia do dzisiejszego, szczególnie młodego, odbiorcy $^{20}$. Będąc zatem niewątpliwym produktem epoki ${ }^{21}$, ND zaproponował zupełnie inną, wymuszoną przez nowe warunki, jakość literatury, w której kwestie etyczne - przede wszystkim to, jak powinien/nie powinien żyć i postępować człowiek - zaczął przekazywać nie w formie gotowych sądów, lecz w formie kompilacji/ kolażu metaforycznych obrazów (sytuacji, ludzi itp.) i opowiadanych historii, prowokujących czytelnika do stawiania pytań na ważne i trudne tematy wypływające z problemów ponowoczesnego świata.

Charakteryzując przemiany współczesnej dramaturgii rosyjskiej w przestrzeni posttotalitarnej, trzeba też pamiętać, że jak cała literatura po rozpadzie ZSRR przeszła ona wszystkie stadia rozwoju twórczości wolnej — od zachwytu odzyskaną wolnością i Zachodem, po negację wszystkiego, co się z nim wiązało. Bezpośrednio po uwolnieniu literatury spod działania czynników politycznych zanika w niej odgórnie narzucany, dyktowany ideologią negatywny stosunek do Zachodu, wyczuwa się euforyczne nastawienie do otwarcia się na jego kulturę, z jego wolnością i różnorodnością estetyczną, postmodernistyczną grą z tradycją, otwartością realizowania trudnych tematów, upodobaniem do szokowania i epatowania innością. Bardzo szybko jednak odmitologizowuje się Zachód w literaturze, pokazując, że ma on również wady, że nadużywanie swobód i bezkrytyczne przyswajanie obcych wzorców kulturowych niesie z sobą ryzyko anihilacji. Komercjalizacja życia i sztuki, uprzedmiotowienie człowieka, brak komunikacji, nieumiejętność przystosowania się do życia w popieriestrojkowym świecie, rozpad tożsamości znajdą wyraz w sztukach Werona (Верона, 1989), La fünf in der lüft (Ла фюнф ин дер люфт, 1992), Trupoj żywy (Трупой жив, 1992) Aleksieja Szypienki; Wibrator (Фаллоимитатор, 1995), Wielki Mur Chiński (Великая китайская стена, 1996) czy Telefunkeny (Телефункен, 1998) Olega Bogajewa; Europa-Azja (Европа-Азия, 2000), Udajac оліаrę (Изображая жертву, 2002), Terroryzm (Терроризм, 2002) Władimira i Olega Priesniakowów.

Twórczość dramaturgiczna tego okresu pełna jest tragicznych historii o wolności, kuszącej zwłaszcza młodzież swobodą destrukcyjnych działań, swoim gwałtownym charakterem, naruszaniem zakazów, grą ze śmiercią. Bohaterem sztuk często jest właśnie młodzież upajająca się brakiem ograniczeń w sytuacji, kiedy stary system wartości runął, a nowy nie miał jeszcze szans ustalić się i utrwalić. Tymi

${ }^{20}$ A jeśli już traktować to pisarstwo w kategorii drogowskazu, to bliższa dzisiejszemu odbiorcy byłaby „linia” Szałamowa, który, doświadczywszy łagrów, opisywał je raczej — jak metaforycznie określa to Wiktor Jerofiejew - niczym Pluton, „który wynurzył się z piekła i pojął »iluzoryczność i ciężar nadziei «" (ibidem, s. 339).

${ }^{21}$ Pisze o tym np. G. Szymczak, Wiktor Pielewin: zabawa w postmodernizm, [w:] Literatura rosyjska na rozdrożach XX wieku, red. W. Skrunda, „Studia Rossica” XII, Warszawa 2003. 
zagadnieniami zajmowali się Szypienko, Nikołaj Kolada, Wasilij Sigariew czy Iwan Wyrypajew. Za przykład niech posłuży najgłośniejsza, ciesząca się uznaniem krytyki i wielokrotnie nagradzana sztuka Plastelina (Пластилин, 2000) ${ }^{22}$ Sigariewa. Utwór jest dramatyczną opowieścią o losach czternastoletniego Maksa, wychowywanego przez babcię, buntującego się przeciwko złu świata, w jakim przyszło mu żyć. Tropiąc rodzące się w szkole zło i próbując mu się przeciwstawić, płaci za swoją szczerość i prawdomówność najwyższą cenę - ponosi śmierć z rąk nieco starszych od niego młodocianych oprawców. Napiętnowany przez otoczenie Maks, nierozumiany przez najbliższych, marzący w swoich snach o miłości, dobru i sprawiedliwości jest postacią literacką bardzo symboliczną dla scenopisarstwa czasów transformacji: zamknięty w sobie, krnąbrny i wulgarny nastolatek, skrywający pod maską obojętności pokłady ciepła i miłości (o czym świadczy jego stosunek do wychowującej go staruszki), w istocie jest wytworem chorych układów społecznych tamtych czasów. Postrzegany jako „błąd natury” jest odrzucany przez społeczeństwo, które wykreowało jego negatywny obraz pod wpływem skrzętnie pielęgnowanego stereotypowego myślenia o dzieciach osieroconych, biednych, zaniedbanych. Ta smutna historia chłopca skrzywdzonego przez los i ludzi służy dramaturgowi jako pretekst, by zadać fundamentalne dla dramaturgii i teatru rosyjskiego okresu transformacji pytanie o to, skąd bierze się zło oraz pytanie o stosunek dobra i zła we współczesnym świecie. W ten sposób jeden $\mathrm{z}$ uczniów Kolady realizował założenia estetyczne ND, który nastawiony był od samego początku na „»realność«, »dokumentalizm «, "nowe«», "aktualne«», czyli na autentyzm wypowiedzi, aktywną postawę publiczności, poszukiwanie własnych źródeł kulturowych, prowokację, dominację tekstu w teatrze"23. Warto jeszcze podkreślić, że to właśnie Plastelina dała etykietę — jak to określa Paweł Rudniew - „całemu kierunkowi współczesnej literatury, usiłującej na ruinach imperium zlepić jakikolwiek koherentny obraz dzisiejszego świata"24.

Podobne starania podjął Iwan Wyrypajew, tworząc nową, niezależną scenę, na której nic się nie udaje. W Tlenie (Кислород, 2002) ${ }^{25}$, opowiedzianej biblijnym językiem historii Saszy, który zabił swą żonę w imię tego, co dla niego najcenniejsze - miłości do drugiej kobiety, poraża żywiołowość i kategoryczność wypowiadanych sądów o współczesności, dominuje „chaos zacietrzewionych zaprzeczeń, zamiast spokojnego wskazywania logicznych sprzeczności w argumentacji oponenta - gorączkowe mnożenie tych sprzeczności. Bez najmniejszej dbałości o poprawność swoich wywodów"26. We wcześniejszych Snach $\left(\right.$ CHbl, 1999 ${ }^{27}$ zaś, w onirycznych wizjach młodych ludzi bez imion, Wyrypajew przedstawia największe lęki młodego

22 W. Sigariew, Plastelina, tłum. J. Czech, „Dialog” 2001, nr 2.

${ }^{23}$ I. Lappo, Antybermudzki trójkąt dramaturgii rosyjskiej, „Dialog” 2011, nr 9, s. 79.

24 П. Руднев, Лягушки с крыльями, „Московский Коммерсант” 10.09.2002. Przywołuję za:

K. Kopka, Wasilij Sigariew: Radość, biedy i diabelski karnawał, „Dialog” 2004, nr 7, s. 175.

${ }^{25}$ I. Wyrypajew, Tlen, tłum. A.L. Piotrowska, „Dialog” 2003, nr 6.

${ }^{26}$ K. Kopka, Iwana Wyrypajewa walka o oddech, „Dialog” 2003, nr 6, s. 96.

27 I. Wyrypajew, Sny, tłum. A. Moskwin, „Dialog” 2003, nr 1-2. 
popieriestrojkowego pokolenia, pozbawionego autorytetów, korzeni, tożsamości, eksperymentującego z życiem, próbującego to życie oswoić w odurzeniu narkotykowym. Tak znamienne dla ND poszukiwanie utraconych wartości, autorytetów i próby odbudowywania własnej tożsamości przyjęło u Wyrypajewa formę metafory poszukiwania drzwi do dobra i miłości (Sny) oraz poszukiwania życiodajnego tlenu w bezdusznym świecie pozbawionym sumienia, świecie, który dusi i odbiera oddech, w którym rządzi relatywizm moralny (Tlen). Problematyka twórczości Wyrypajewa oraz innych przedstawicieli ND oscylowała zatem wokół zagadnień egzystowania na „pustyni powstałej po skompromitowaniu się wszelkich dawnych wiar”, gdzie „jedyne, czym możemy się kierować w naszej wędrówce przez rumowisko dawnych wiar i systemów aksjologicznych, to indywidualna świadomość istnienia dobra i zła oraz naszej egzystencji w przestrzeni pomiędzy "nie i tak «" 28 . Uniwersalizm podejmowanych przez Wyrypajewa zagadnień sprawił, że krytycy dostrzegli w sztukach autora Tlenu „udaną próbę dania świadectwa przeżyciu pokoleniowemu dzisiejszych [w 2003 roku - L.M.] dwudziesto-, trzydziestolatków, których dojrzewanie przypadło na okres gwałtownego i dogłębnego przewartościowania całej rosyjskiej (i radzieckiej) tradycji ideowej"29.

Na przeciwległym biegunie poszukiwań nowej tożsamości kulturowej w procesie samoidentyfikacji ND, jaki obserwujemy w posttotalitarnej kulturze rosyjskiej, usytuowała się twórczość Jewgienija Griszkowca. Można w niej bez trudu odnaleźć tę cechę ND, jaką jest autobiograficzność, pomagająca autorom w scalaniu rozbitej, niespójnej tożsamości. Sztuki Griszkowca (często monodramy, które sam realizuje na scenie swojego teatru) są historią nie tylko współczesnego człowieka, zawieszonego w przestrzeni ponad granicami kulturowymi, etnicznymi czy społecznymi. Są to także opowieści o współczesnej Rosji, którą młody twórca poznał dobrze dzięki podróżom podczas służby w marynarce wojennej oraz późniejszym ciągłym przeprowadzkom (Kiemierowo, Moskwa, Kaliningrad). Trzeba podkreślić, że to właśnie ta Rosja jest stale obecna w jego teatrze: opisując podróż po kraju, pisarz przywołuje doskonale znane rosyjskiemu odbiorcy melodie, nuci na scenie fragmenty piosenek, odwołuje się do „powszechnie rozpoznawalnych motywów filmowych i literackich, do życia publicznego i obyczajów, wreszcie do typowych westchnień, reakcji i gestów" ${ }^{30}$. Często drwi z absurdów ówczesnej i dzisiejszej rzeczywistości, swoimi anegdotami dotyka istoty rosyjskości, sięgając do stereotypów, ironizuje na temat Rosji socjalistycznej, totalitarnej. W swoich monodramach, szczególnie w Jak zjadłem psa (Как я съел собаку, 1999) ${ }^{31}$, konfrontuje z jednej strony dzieciństwo i marzenia o przyszłości z dorosłością, która nierzadko rozczarowuje i przynosi klęskę ideałów (dziecięce marzenie chłopca, by zostać marynarzem weryfikuje służba wojskowa, która w dorosłym życiu jest dla niego jedynie przykrym obowiązkiem). Z drugiej

\footnotetext{
${ }^{28}$ Ibidem, s. 97-98.

${ }^{29}$ Ibidem, s. 96-97.

${ }^{30}$ M. Zielińnka, Jewgienij Griszkowiec: swój wśród obcych, „Dialog” 2000, nr 12, s. 107.

${ }^{31}$ J. Griszkowiec, Jak zjadtem psa, tłum. I. Lewandowska, „Dialog” 2000, nr 12.
} 
strony, źródłem rozczarowań, które opisuje Griszkowiec jest zderzenie przeszłości ZSRR z teraźniejszością współczesnej Rosji, znajdującej się w sytuacji ciągłych przemian dezorientujących zwykłego człowieka. Griszkowiec zatem wraca do przeszłości komunistycznej bez nienawiści, z uśmiechem wspomina pierwsze projekcje filmów grozy czy oglądane w dzieciństwie „multiki”. Słusznie zauważa cytowana już Maryla Zielińska, że dramaturg „o Rosji i Związku Radzieckim opowiada bez złości i bólu, nie czuje się w tym resentymentu. Ale też nie wpisuje się w nostalgię za »kochanym Związkiem«, za kiełbasą po rublu trzydzieści za kilo i za lotami w kosmos"32. I mimo że wiele wyobrażeń o Rosji runęło w trakcie odchodzenia od starego modelu państwowości, mimo że jedne pokolenia straciły wiele, podczas gdy inne zyskały możliwość swobodnego przemieszczania się po świecie, kariery na Zachodzie, to w ostatecznym rozrachunku obraz Rosji dawnej i dzisiejszej w teatrze Griszkowca skreślony jest w sposób zarówno ironiczny, jak i nieco romantyczny, przy tym na pewno pozbawiony historycznego ujęcia. Nie można nie zgodzić się w tym miejscu z Katarzyną Osińską, która uważa, że współczesny nowy dramat tak naprawdę cechuje brak refleksji na temat historii, ale też teraźniejszości, albowiem „teraźniejszość, która nie ma korzeni, nie poddaje się refleksji" ${ }^{33}$. ND tworzony przez młode pokolenie dla młodych i o młodych pokazuje dobitnie, że jego bohater ma poczucie braku tożsamości, nie ma tła, jest w pewnym sensie pozbawiony korzeni, ponieważ tym młodym ludziom (i autorom, i protagonistom sztuk)

przeszłość objawia się [...] albo jako zbiorowy rytuał (jak świętowany 9 maja Dzień Zwycięstwa), nierewidowany, zatem łatwy do wyszydzenia, albo pod postacią okruchów, fragmentów, raczej odnoszących się do radzieckiej codzienności niż do historycznych doświadczeńn ${ }^{34}$.

Ten ostatni sposób odniesienia do rzeczywistości jest domeną twórczości przywołanego właśnie Griszkowca, który pokazuje, że po totalitaryzmie zbiorowe mity zostały zastąpione mozaiką klisz i stereotypów.

„Przedrzeźnianie” i wyszydzanie rzeczywistości (historii i współczesności) odnajdziemy z kolei u Władimira Sorokina. Dla pisarza Rosja stanowi najciekawszy temat, któremu od lat poświęca swoje utwory, choć sam, prowokacyjnie, zaprzecza temu, mówiąc: „Nie mam zainteresowań społecznych. Jest mi wszystko jedno — zastój czy pieriestrojka, totalitaryzm czy demokracja"35.

Autor Kolejki (Очередь, 1983) wszedł do literackiego podziemia w latach siedemdziesiątych ubiegłego wieku jako artysta socartowy, pozostający pod silnym wrażeniem twórczości Erika Bułatowa, dzięki któremu zmienił swój stosunek do estetyki.

${ }^{32}$ Ibidem, s. 108.

${ }^{33}$ K. Osińska, Gry z przeszłością. Uwagi na marginesie Festiwalu Złota Maska, „Dialog” 2004, nr 7, s. 183.

34 Ibidem.

35 Cyt. za: T. Klimowicz, Przewodnik po wspótczesnej literaturze rosyjskiej i jej okolicach (19171996), Wrocław 1996, s. 653. 
Dotąd - mówi Sorokin - postrzegałem proces historyczny i kulturalny jako przerwany w latach dwudziestych i wciąż żyłem przeszłością - futurystami, dadaistami, oberiutami. A tu nagle zobaczyłem, że nasz monstrualny świat radziecki ma własną, niepowtarzalną estetykę, którą się ciekawie uprawia, która funkcjonuje według własnych reguł i jest absolutnie równoprawna w łańcuszku procesu kulturalnego ${ }^{36}$.

Dystansując się do kultury w ogóle, mówiąc, że literatura, to tylko papier, który wszystko zniesie ${ }^{37}$, Sorokin wykorzystuje jako materiał i narzędzie zarazem poetykę socrealizmu, by obalać mity świata radzieckiego oraz wyśmiewać rzeczywistość sowiecką i postsowiecką. Teksty Sorokina nie zawsze są łatwe w odbiorze ze względu na jego „chorobliwą skłonność do ukazywania obszarów wzbudzających wstręt" ${ }^{\text {", }}$, manifestującą się obrazami patologii, dewiacji seksualnych, skatologii, obrazami okraszonymi żywym, niecenzuralnym językiem określonych grup społecznych czy zawodowych, językiem ulicy. Pisarz uwielbia szokować, epatować, zaskakiwać, wprawiać w zdumienie i tym samym wzbudzać skrajne emocje.

W napisanej specjalnie dla Teatru Praktika sztuce Kapitał (Капитал, 2006) $)^{39}$ Sorokin próbuje, jak w wielu swoich utworach, zademonstrować absurdy życia w popieriestrojkowej Rosji. Przedstawia grupę kapitalistów, biznesmenów oligarchów, którzy usiłują walczyć o rozwój własnego holdingu, o jego dobrą pozycję. Od początku jednak ich działania skazane są na niepowodzenie, ponieważ przyszło im działać w pozbawionej pozytywów ponurej rzeczywistości Rosji lat dziewięćdziesiątych XX wieku, gdzie doświadczają wielu krzywd. Starając się oddać osobliwą estetykę, znamionującą ówczesny świat rosyjskiego biznesu, Sorokin każe menadżerom grać w absurdalną, typową dla jego konceptu grę, nazwaną tu „zaduś chodora”. I analogia do losów Michaiła Chodorkowskiego jest tutaj absolutnie celowa, a skojarzenia z jego losami wręcz pożądane. „Zadusić chodora” oznacza bowiem zduszenie w sobie poczucia krzywdy, uporanie się z poczuciem niesprawiedliwości oraz „przełknięcie” wstydu za kraj, w którym każda uczciwa praca, nowa pozytywna inicjatywa okazuje się udręką i w majestacie prawa jest duszona w zarodku.

Pojawiają się tutaj typowe dla Sorokina kwestie związane z sumieniem, oczyszczaniem sumienia, z poczuciem winy i towarzyszącą im - najczęściej w finale - próbą przezwyciężenia kryzysu w formie zbiorowej spowiedzi bądź innego rytualnego aktu o takim charakterze. Szokujące treści, desakralizowanie świętości, obnażanie stereotypów, łamanie tabu wykorzystywane są przez pisarza po to, by zmusić odbiorcę do jakiejkolwiek zdecydowanej reakcji. Sam Sorokin przyznaje, że

${ }^{36}$ Ibidem.

37 В культуре для меня нет табу. Владимир Сорокин отвечает на вопросы Сергея Шаповала, [w:] В. Сорокин, Собрание сочинений в двух томах, t. 1, Москва 1988, s. 10. Przywołuję za: A. Wołodźko-Butkiewicz, Grabarz literatury rosyjskiej? Spory wokół Władimira Sorokina, „Przegląd Rusycystyczny" 2003, nr 3, s. 74.

38 W. Kasack, Leksykon literatury rosyjskiej XX wieku. Od początku stulecia do roku 1996, tłum., oprac., bibliografia polska i indeks osób B. Kodzis, Wrocław 1996, s. 594.

39 Sztuki dostępne są na stronie internetowej Sorokina, www.srkn.ru/texts [dostęp: 8.01.2012] oraz w tomie В. Сорокин, Капитал. Полное собрание пьес, Москва 2007. 
po lekturze jego tekstów: „czytelnicy mogą nawymyślać w listach, czasem wybuchnie pyskówka na wieczorze autorskim. Ale dla pisarza - mówi - najgorsza jest obojętność. Głównie gromią mnie spadkobiercy sterylnej sztuki socrealistycznej” - dodaje ${ }^{40}$.

I istotnie, udaje mu się poruszyć odbiorców, także polskich, którzy — dla przykładu - po premierowym spektaklu Podróż poślubna (Teatr Jeleniogórski, 2007, reż. I. Vedral) niejednokrotnie zastanawiali się, czy aby na pewno mieli do czynienia ze sztuką, $\mathrm{z}$ teatrem, $\mathrm{z}$ udawaniem, odgrywaniem ról. Podpatrywanie przez Sorokina życia i ludzi - do czego także przyznaje się wprost, mówiąc, że z przyjemnością obserwuje i naśladuje to, co się wokół niego dzieje - definiuje jego estetykę. Dlatego w swoich tekstach stara się — nie jak inni „aroganccy”, jak ich nazywa, pisarze uciekający od brzydoty i zła, marzący o Wielkiej Rosji w zaciszu własnych gabinetów - być aktualny i być blisko świata, który opisuje czytelnikom to, co dla innych twórców jest „brzydkie, okropne, sprzedajne, brudne i złe” 41 . I mimo że dzięki temu przylgnęła do niego etykietka, niesłusznie - jak sam zauważa - pisarza, którego fascynuje zło, usiłuje wciąż, tak jak w jednym z pierwszych opowiadań pt. Miesiąc w Dachau (Месяи в Дахау, 1994), wyjaśnić sobie samemu, dlaczego ludzie nie potrafią uwolnić się od zła i co unicestwia dziś człowieka ${ }^{42}$.

W sztuce Podróż poślubna (Hochzeitreise, 1994-1995) Sorokin „z charakterystyczną dla tzw. postmodernistów beztroską żongluje [...] najprymitywniejszymi kliszami skojarzeniowymi i narodowymi stereotypami”"43, by obnażyć schematyczne myślenie o Historii oraz pokazać „Rosję pełną absurdu, groteski i szaleństwa” ${ }^{44}$. Oto bowiem fabuła omawianej sztuki osnuta jest wokół miłości, zaskakującej jak zawsze u Sorokina, między rosyjską Żydówką, emigrantką, córką Róży — oficer śledczej NKWD, a młodym artystą, bogatym Niemcem, synem Fabiana - oficera SS. Oboje noszą na sobie brzemię Historii, oboje przygnieceni ciężarem niechlubnej przeszłości własnych rodziców gubią tożsamość bądź popadają w etycznie kłopotliwe obsesje.

Masza Rosenthal, młoda wyzwolona kobieta, lubi ostry seks i kwaszone ogórki, czuje swoją żydowską krew, jednak nie potrafi płakać pod Ścianą Płaczu, odrzucając przeszłość, zachowuje dobre zdrowie i apetyt na życie. Günter von Nebeldorf, jej mąż, z kolei nie może uprawiać seksu bez poczucia winy, przejawia skłonności masochistyczne oraz oddaje się pasji kolekcjonowania judaiców. Opętany przez przeszłość, zmagający się z poczuciem winy jest człowiekiem chorym, nie bardziej jednak

40 Pierwszy pornograf Rosji. Z pisarzem Władimirem Sorokinem rozmawia Anna Żebrowska, „Duży Format” nr 7, dodatek do „Gazety Wyborczej” nr 37, 14.02.2005, s. 6.

${ }^{41}$ Pisarz, kawior, wódka. Z Władimirem Sorokinem rozmawiał w Moskwie Marcin Wojciechowski, http://wyborcza.pl/1,75475,2496652.html [dostęp: 20.08.2011].

${ }^{42}$ Nieludzki punkt widzenia. Rozmowa Krzysztofa Masłonia z Władimirem Sorokinem, http:// archiwum.rp.pl/drukuj/528929.html [dostęp: 3.09.2011].

43 G. Kondrasiuk, Trzy żydowskie opowieści, http://www.e-teatr.pl/pl/artykuly/60546.html?josso_ assertion_id=BD6508AB6B646C73 [dostęp: 29.08.2011].

44 A. Romanowska, Demoludy. Dzień trzeci, http://www.e-teatr.pl/pl/artykuly/57871.html [dostęp: 1.09.2011]. 
niż Masza, której „całkowita niezdolność do identyfikacji z przeszłością jest patologią" ${ }^{35}$. Sorokin w prześmiewczym tonie, $\mathrm{w}$ prowokacyjny sposób konfrontuje z sobą opowieści o wojnie, o Holokauście i o wolności, pokazując, że współczesną Europą kieruje myślenie spod znaków SS i NKWD. Ponadto, jak zauważa Łukasz Drewniak:

Sorokin przeprowadza swoich bohaterów przez korytarze pełne obelżywych paradoksów. [...] I jest tak, jakby sam towarzysz Stalin kopulował z Adolfem Hitlerem. Konfrontacja Wschodu i Zachodu w oczach Sorokina to zderzenie puszczalskiego i dotkniętego amnezją syberyjskiego szczepu $\mathrm{z}$ dekadenckim, pełnym traum i win starym światem ${ }^{46}$.

Zderzenie to służyć ma oczyszczeniu, przezwyciężeniu i przepracowaniu traum XX wieku właśnie dzięki krzywemu zwierciadłu, w którym bez litości odbijają się krzywdzące stereotypy. Sorokin nie byłby ponadto sobą, gdyby i samych bohaterów nie poddał terapii: oto Masza, chcąc wyciągnąć męża z więzienia przeszłości, urządza mu seans psychoanalityczny - obwozi go ubranego w mundur esesmana po całych Niemczech. By w pełni przepracować traumę, Günter musi na koniec dokonać pewnej rytualnej czynności w dziękczynnej kaplicy rodu Nebeldorfów. W odprawieniu rytuału przeszkadza mu jednak furgonetka wypełniona tuszami wieprzowymi z gatunku marmurkowych, zawieszonymi na hakach, pojawiająca się niczym spełnienie ciążącego nad nim fatum (ojciec bohatera wieszał swoje ofiary - Żydów na hakach rzeźniczych). Dopełnieniem absurdu tej sytuacji jest umieszczona na samochodzie, złowieszczo brzmiąca dla Güntera nazwa producenta żywności: „Róża Abzatz i Fabian Haken. ŚWINIE MARMUROWE”. Furgonetka rozbija kapliczkę, manie powracają, Günter znów się jąka, wszystko cofa się do dawnego „porządku”. W zakończeniu sztuki słychać zatem chichot losu, przyszli małżonkowie nie zdołali wypowiedzieć w kapliczce słów, jakie od pokoleń miały być gwarancją zapomnienia, szczęścia i dobrobytu („Свяжи себя с Туманом!”, „Твой дом не будет пуст!”) ${ }^{47}$ i skazują się tym samym na dalsze życie w cieniu własnych niechlubnych historii, pośród nieprzepracowanych traum.

W swoich sztukach Sorokin odważnie i obrazoburczo śmieje się więc z rzeczy moralnie niewygodnych, co skazuje go bardzo często na niezrozumienie czy wręcz odrzucenie przez krytykę i zwykłego czytelnika, nieprzygotowanego na żonglowanie nieprzystającymi do siebie estetykami i wielkimi narodowymi mitami, zakorzenionymi w zbiorowej podświadomości radzieckiej historii. Konstantin Bogomołow, przedstawiciel młodego pokolenia reżyserów rosyjskich, opisując reakcję publiczności na swoją autorską interpretację Wielkiej Wojny Ojczyźnianej, w której to wizji zrównuje ideologię stalinowską z hitlerowską (przedstawienie Lear. Komedia/Лup.

${ }^{45}$ K. Osińska, op. cit., s. 182.

46 Ł. Drewniak, Nienasza Masza, http://www.e-teatr.pl/pl/artykuly/59718.html [dostęp: 5.09.2011].

47 „Zwiąż się z Mgłą!”, „Twój dom nie będzie pusty!”. В. Сорокин, Hochzeitreise, [w:] idem, Kaпитал. Полное собрание пьес, s. 242. 
Комедия, Teatr „Prijut Komedianta”, Petersburg, 2011, reż. K. Bogomołow), wyraża opinię znakomicie charakteryzującą także teatr Sorokina:

Paradoksalnie [widzów bulwersuje - L.M.] nie tyle spojrzenie na wydarzenia historyczne, co sposób rozmowy o historii. Nie sama myśl oburza - Bóg z nią!, mało kto ją rozumie: Szekspir z dołączonym jakimś Nietzschem, Celanem, gdzieś tam swastyka na rękawie... Najbardziej oburza połączenie komiksowej formy ze świętą rzeczywistością. Że ci ludzie, ze Stalinem na czele, którzy przecież kiedyś byli żywi, byli prawdziwi, w spektaklu są tacy obleśni, sparodiowani, pozbawieni psychologii. Pozbawienie ich cech ludzkich wzbudza bardzo silne oburzenie, nawet jeśli ci, o których się mówi, nie byli ludźmi ze względu na to, co robili. Bo w Rosji sztuka powinna być humanistyczna i zawsze mówić o dobru, być rodzajem przypowieści czy bajki, a nie formą szczerej rozmowy ${ }^{48}$.

Obnażając mechanizmy opresywności dyskursu władzy i mowy nienawiści, ograniczeń nakładanych przez tradycję, przez przynależność do jakiegoś społeczeństwa, języka, pokazując terroryzm nie tylko polityczny, lecz także emocjonalny czy mentalny (Mark Lipowiecki), wyraża Sorokin bunt przeciwko tabu, ojcu-despocie, państwu, systemowi itd. i nie pozwala czytelnikowi pozostać obojętnym, zdystansowanym, lecz także „zabiera go do środka, do świata rozgrywającego się w głowach bohaterów, w samo apogeum szaleństwa" ${ }^{39}$.

W takim punkcie kulminacyjnym obłędu znajdują się też odbiorcy sztuk Michaiła Wołochowa, który podobnie jak Sorokin nie skupia się wyłącznie na opisach absurdu ludzkiej egzystencji. Z ogromnym zainteresowaniem podejmuje zagadnienia absurdu i grozy, charakteryzujące wzrastające w siłę totalitaryzmy, z których rodzą się antyludzie.

W sztuce Czapa Czikatiło (Вышка Чикатило, 1994-2006) ${ }^{50}$ główny bohater, seryjny morderca dzieci (wzorowany na historycznej postaci Andrieja Czikatiły - Rzeźnika z Rostowa), próbuje umniejszyć swoje winy, mówiąc, że postępował zgodnie z wypracowaną przez Lenina i Stalina moralnością, która zrodziła w społeczeństwie wzorce maniakalnych zachowań. W utworze Gra w umarlaka (Игрa в жмурики, 1987) dwaj oprawcy, agenci KGB Arkadij i Feliks, prowadzą w kostnicy rozmowę o celach i efektach ich pracy, o metodach przynoszących najlepsze wyniki w ich śledztwach. Pomiędzy opisy okrucieństw, jakich się dopuszczali, wplatają krótkie i celne uwagi do świata komunistycznego z jego absurdami, także językowymi (posługują się nowomową). Podobnie „przedrzeźniają” rzeczywistość socrealistyczną dwaj zecy Kołek i Globus, uciekający z syberyjskiego łagru do Paryża na dachu pociągu towarowego w sztuce I do Paryża (И в Париж, 1995). W ich rozmo-

${ }^{48}$ Wypowiedź Konstantego Bogomołowa pochodzi z rozmowy z Anetą Kyzioł, zamieszczonej w: Katalog Festiwalu Да! Да! Да! Wspótczesny teatr, dramat i performans $z$ Rosji. 17 maja-22 czerwca 2013, Warszawa 2013, s. 39.

49 E. Adamiszyn, Literatura i narkotyki, http://www.e-teatr.pl/pl/artykuly/65638.html [dostęp: 17.08.2011]. Zob. też recenzję tego spektaklu, zamieszczoną na tej stronie www.e-teatr.pl: M. Sulecki, Premiera: Dostojewski zadziała jak narkotyk. A także recenzję Anity Nowak zamieszczoną na http:// teatr.torun.pl/portal.php?aid=12697955254baf8ac595b34 [dostęp: 10.07.2011].

${ }^{50}$ Sztuki M. Wołochowa dostępne na stronie http://volokhov.ru/site/ [dostęp:19.03.2015]. 
wach o Bogu, egzystencji, literaturze odnajdziemy ironiczne, wręcz sarkastyczne komentarze do rzeczywistości radzieckiej ponownie ujawniające absurdy tamtych czasów i mechanizmy rodzącego się wówczas zła. Kreując postacie „ludzi z podziemia”, wyalienowanych indywidualistów - morderców, oprawców, złoczyńców - i podejmując temat zła oraz śmierci, Wołochow przekonuje odbiorcę, że każdy człowiek może odkryć w sobie pokłady kłamstw i nieskrępowaną agresję. Eduard Bojakow, interpretując tę sztukę, przyrównuje tak pokazane najciemniejsze instynkty ludzkie do wewnętrznych zeków, makabrycznych istot, zasiedlających każdego z nas ${ }^{51}$.

W ten sposób, jak się zdaje, to właśnie estetyka absurdu i poetyka teatru absurdu wykorzystywana przez Sorokina i Wołochowa służy do zdekonstruowania radzieckiego projektu rzeczywistości i jego obrazu w literaturze. Dzięki elementom satyrycznym obnażone zostają absurdy pozornie szczęśliwego życia w warunkach państwa totalitarnego, które zmusza do egzystencji w rzeczywistości kłamliwej i zdeformowanej przez język, politykę oraz działania społeczeństwa ${ }^{52}$.

Trzeba jednak powiedzieć, że demitologizowanie radzieckiej historii poprzez bezpośrednie odwołania do tejże pojawia się w ND niezbyt często. Lektura najnowszych dramatów pokazuje, o czym była mowa wyżej, że ND wprowadzał nowe tematy i problemy, skupiając się na traumie socjalnej (traumatyczne przeżycia związane z okresem transformacji i jej dalekosiężne skutki) i wypierając przeszłość, „wyciskając ją ze świadomości ostatnich pokoleń urodzonych w ZSRR, unieważniając całe radzieckie doświadczenie" ${ }^{33}$. Przyczyny takiego stanu rzeczy precyzyjnie diagnozuje przywoływany już Bogomołow, potwierdzając cytowaną na początku niniejszych rozważań konstatację Sorokina:

Rosja nie przepracowała swojej przeszłości - mówi reżyser w wywiadzie dla „Gazety Wyborczej”. — Nie mamy odwagi szczerze porozmawiać o naszej historii z nowymi pokoleniami. Boimy się historii, znajdujemy niekończące się wymówki, by o niej nie mówić. To upokarzające dla kraju i obywateli. Państwowa mitologia w Rosji — tak jak w każdym innym kraju — to mur, za pomocą którego państwo broni się przed uczciwym spojrzeniem ${ }^{54}$.

Nie dziwi więc fakt, że twórcy, ale też odbiorcy, stroniącemu od historii i przyzwyczajonemu do rozrywki w teatrze, do „milutkości, dobroci, przenikliwości, wyższych prawd" podanych na talerzyku ${ }^{55}$, o wiele łatwiej przyjąć inny model rozliczenia się z przeszłością $\mathrm{w}$ literaturze, jakim będzie czerpanie $\mathrm{z}$ doświadczeń postmodernizmu zachodniego i wykorzystywanie przez przywołanych pisarzy absurdalnej gry

51 Великая Отечественная Игра современной драматургии, http://culture.pravda.ru/theatre/ premiers/12-04-2006/81461-0/\# [dostęp: 12.09.2014].

52 Zob. A. Krajewska, Dramat i teatr absurdu w Polsce, Poznań 1996, s. 14.

53 A. Karaś, Teatr rosyjski: między pamięcią a zapomnieniem, [w:] Katalog Festiwalu Дa! Дa! Да! Wspótczesny teatr, dramat i performans $z$ Rosji, s. 14.

${ }^{54}$ Materiały prasowe dedykowane premierze (25.01.2014) spektaklu Lód w reż. K. Bogomołowa w Teatrze Narodowym, http://iam.pl/pl/download/material_prasowy/node-field_download_zip-325-0 [dostęp: 14.04.2015].

55 I. Lappo, Antybermudzki trójkąt dramaturgii rosyjskiej, „Dialog” 2011, nr 9, s. 90. 
z autorami i tekstami przeszłości. Nie sprowadza się ona jednak do zwykłej przeróbki czy adaptacji tekstu klasyków, jak czyniły to wcześniejsze pokolenia pisarzy, lecz przybiera formę gry znanej z działalności socartystów, którzy „przedrzeźniali” socrealizm. Powszechnie funkcjonujące w świadomości odbiorcy motywy, postacie, cytaty z literatury umieszcza się w nowym, odmiennym od pierwotnego kontekście, by uzyskać komiczny czy wręcz groteskowy efekt. Wystarczy przywołać sztuki: Trupoj żywy Aleksieja Szypienki; Jubileusz (Юбилеŭ, 1993) i Dostoevsky trip (Dostoevsky trip, 1997) Sorokina; Martwe uszy, czyli najnowsza historia papieru toaletowego (Мертвые уши или новейшая история туалетной бумаги, 1998) і Ваszтасzkin (Башмачкин, 2000) Olega Bogajewa; Śmierć Ilji Iljicza (Смерть Ильи Ильича, 2000) Michaiła Ugarowa; Mewa (Чайкa, 2000) Borysa Akunina; „Mewa” A.P. Czechowa (remix) («Чайка» А.П. Чехова (remix), 2002) Konstantina Kostienki; Zniewolone duchy (Пленные духи, 2002) Olega i Władimira Priesniakowów; Bracia Cz. (Братья Ч., 2010) Jeleny Grieminy; Aleksy Karenin (Алексей Каренин, 2011) Sigariewa i wiele innych. We wszystkich celem nadrzędnym jest chęć (w duchu postmodernistycznej poetyki) zderzenia w utworze wartości wysokich z przyziemnością codzienności, skonfrontowanie wyobrażeń ikon rosyjskiej kultury z ich zmanipulowanymi na potrzeby konkretnego tekstu reinterpretacjami. Katarzyna Osińska dokładnie opisuje ten mechanizm, przekonując, że u źródeł „przedrzeźniania” rzeczywistości leży

przemożna chęć odreagowania autorytarnego modelu kultury rosyjskiej, w której w roli autorytetu występowali między innymi klasycy literatury. Owa postmodernistyczna gra z przeszłością i jej atrybutami [...] jest w gruncie rzecz wynikiem niemożności uporania się - nie tylko zresztą przez teatr $-\mathrm{z}$ rzeczywistością zarówno tą dzisiejszą, jak i wczorajszą, radziecką ${ }^{56}$.

Jak widać zatem, lata osiemdziesiąte i początek lat dziewięćdziesiątych XX wieku to czas podejmowania w rosyjskiej dramaturgii współczesnej nieśmiałych prób rozrachunku z przeszłością, trudnego dialogu z historią. Po 1991 roku, po rozpadzie ZSRR, następuje jednak zmiana problematyki z politycznej i/lub historycznej na społeczną, co wydaje się wynikiem obserwowanych przez pisarzy przemian w społeczeństwie: dostrzegano i opisywano problemy wypływające z niedostosowania do czasów transformacji, kwestie rozwarstwienia społeczeństwa, niedostatku, rozpadającego się życia. Tego typu aktualne problemy czasów transformacji, problemy codzienności dominowały w dramacie aż do początków XXI wieku, kiedy to nastąpił ponowny zwrot do tematów historycznych w teatrze, o czym świadczy choćby działalność Bogomołowa, nazywanego Sorokinem teatru współczesnego. Przywołać tu można jeszcze sztuki, takie jak: Cekaemista (Я - пулеметчик, 2004) Jurija Kławdijewa, Pawlik - mój Bóg (Павлик - мой Бог, 2007) Niny Bielenickiej czy Frontowiczkę (Фронтовичка, 2008) Anny Baturiny. Być może więc jesteśmy świadkami narodzin swego rodzaju dramatu postpamięci, o którym Anna Burzyńska

${ }^{56}$ K. Osińska, op. cit., s. 180. 
powie, że jest pamięcią tego, co pozostało, refleksją nad tym, co z przeszłych wydarzeń zostało zapamiętane. Za podsumowanie powyższych rozważań mogłyby służyć słowa jej komentarza do problemu dialektyki narodowej pamięci zbiorowej i amnezji w twórczości Michała Zadary:

Teksty literackie, w których [...] obsesyjnie powracają traumatyczne obrazy przeszłości, są [...] równie wyrazistym, co milczenie dowodem, że traumy są wciąż nieprzepracowane. Paradoksalnie, poprzez ciągłe powracanie, nabierają one cech zdarzenia mitycznego. W teatrze [...] mit rodzi się bowiem na ruinach: w pół drogi pomiędzy pamięcią i amnezją ${ }^{57}$.

Najnowszy dramat rosyjski, próbując odnaleźć własną tożsamość kulturową w posttotalitarnej przestrzeni kultury, zdaje się funkcjonować między ową pamięcią i amnezją. Czasem uruchamia pokłady pamięci po to, aby w innej swojej odsłonie wyprzeć traumatyczne doświadczenia. Stąd wielość form wyrazu i wielokierunkowość poszukiwań estetycznych w ND rosyjskim, który bazuje na tradycji, ale też nie stroni od eksperymentów formalnych. Realizm, neorealizm, postrealizm, konceptualizm, postmodernizm, teatr dokumentalny, teatr metaforyczny, teatr dekonstrukcji, teatr absurdu, liczne teatry laboratoria: teatr.doc (Ugarow), Teatr Praktika (Wyrypajew), Teatr Post (Dmitrij Wołkostriełow), Kolada Teatr (Kolada) i wreszcie performatywne praktyki Pawła Priażki (szczególnie projekty Żołnierz/Солдаm, 2011 oraz Jestem wolny/Я свободен, 2012) - wszystkie te kategorie estetyczne i formy działalności teatralnej wzbogacają postsowiecki pejzaż kultury rosyjskiej i z pewnością dynamizują jej mechanizmy. Niestety unaoczniają również prawdę o tym, że do dzisiaj nie można mówić o teatrze politycznym w Rosji, że tylko nieliczni wskazują na groźbę odrodzenia się totalitaryzmu w Rosji, na groźbę ekspansji na inne kraje świata, czy krytykują ideologię komunistyczną jako utopijną, usprawiedliwiającą historyczny gwałt i ludzkie ofiary, tak jak czynią to Pietruszewska, Sorokin czy Wołochow. Wskazują zatem, że przed dramatem i teatrem rosyjskim pozostaje wciąż długa i ciężka praca z własną historią, pamięcią i traumą.

57 A.R. Burzyńska, „Myśmy wszystko zapomnieli”. Dialektyka narodowej pamięci i zbiorowej amnezji w teatrze Michała Zadary, [w:] 20-lecie. Teatr polski po 1989, red. D. Jarząbek, M. Kościelniak, G. Niziołek, Kraków 2010, s. 68. 